\title{
Consequences of location lighting systems in historical buildings
}

\begin{abstract}
The article deals with problems of indoor lighting in historic buildings. These are consequences of placing the built-in electrical system which affects the cultural and historical values by modernization of the building. There are interventions into building construction. The methodology of heritage preservation applies the principle of reversibility in new interventions. Its fulfilments in practice is difficult since it requires careful preparation for implementation. In this contribution we present a selection and description of frequent situations. In the end we refer comments for practice on designing and methodology for protection of cultural heritage.
\end{abstract}

Keywords: conservation and restoration, reversibility, interior lighting, electrical wiring, upgrading the interior of churches

\section{1 Úvod}

Súčasná obnova pamiatkových objektov prináša so sebou modernizácie a adaptácie, kde $v$ mnohých prípadoch je primárnou úlohou nové umelé osvetlenie. Z hl'adiska pamiatkového záujmu, teda ochrany a prezentácie kultúrno-historických hodnôt interiérov aj exteriérov pamiatkových objektov, je potrebné $v$ tejto súvislosti sledovat':

a) viditel'né účinky svetla - čo a ako bude osvetl'ované; b) viditel'nú osvetl'ovaciu sústavu - osvetl'ovacie telesá, ovládacie prvky a pod c) zabudovanú sústavu - elektro-rozvody, ovládacie a rozvodné skrine a pod.

Článok sa venuje okruhu b) a c) v situáciách, ktoré sa priamo týkajú problematiky reverzibility. Reverzibilita je v pamiatkovej obnove chápaná ako jedna zo základných uplatňovaných zásad. [1,Gregor,2008] Metodicky a prakticky pri realizácii sa týka „kontaktu nového a starého“. Vychádza z princípu zachovania originálu a znamená schopnost' odňatia zásahu a zároveň vrátenie do pôvodného stavu pred zásahom, respektíve ponechanie stavu pred zásahom. Uvádza sa aj termín „opakovatel'nost' / retreatibilty"[2,Erdélyi]. Za nereverzibilné môžeme považovat' zásahy nevratné, čiže výraznú stratu a výrazné porušenia originálov - materiálových substancií, a tým pádom narušenie pamiatkových hodnôt. Nie každý zásah musí byt' reverzibilný, ale je požadované hl'adat' riešenia, ktoré uvedenému princípu vyhovujú. Posúdenie je individuálne, vzhl'adom na charakteristiku zásahu a vo väzbe na kultúrno-historické hodnoty konkrétneho objektu a k povahe iných paralelných zásahov.

Dôsledky na materiálovú podstatu objektov sú samozrejme vyvolané z budovania aj d’alších technických sietí pre zlepšenie pobytového štandardu. Ide o vetranie/klimatizáciu, ozvučenie, temperovanie. Technická modernizácia vyvoláva všeobecne menšie zásahy, ale o to podrobnejšia a dôslednejšia musí byt' projektová príprava. (Poznámka: sanácie zásahov vyvolané stavebnou diagnostikou, napr. statické zabezpečenie, odvlhčenie a iné teraz neuvádzame).

Predmetom príspevku je upozornenie na dôsledky stavebných zásahov z hladiska pamiatkovej ochrany vyvolaných modernizáciou osvetlenia. Uvedené reprezentatívne príklady sú vybrané z frekventovaných situácií pri realizácií na sakrálnej architektúre. Výber upozorňuje na fakt, že dôsledky novej osvetlovacej sústavy so svojou zabudovanou zložkou sú rovnako dôležité pre zachovanie pamiatkových hodnôt, ako vplyvy viditel'nej zložky. (Kam logicky zaradíme napr. vzhl'ad osvetl'ovacích telies, ktorý $v$ tomto prípade neberieme do úvahy, ani účinky produkovaného svetla).

\section{Vybrané sledované situácie}

\subsection{Trasovanie rozvodov.}

Trasovanie káblov pod omietkami k svietidlám umiestneným na stenách predstavuje bežný príklad. Dnes sa pôvodné vedenia korigujú, nahrádzajú sa staré káble aj trasy, vznikajú nové z dôvodov pokročilejších technológií. Zo starších skúseností je zrejmé, že pod určitými omietkami môžeme očakávat' staršiu umeleckú výzdobu. Je preto potrebné pred realizáciou potvrdit' a spresnit' trasy na mieste, tak zo strany dodávatel'a prác aj pamiatkového úradu. Výkresová projektová dokumentácia nových elektroinštalácií nezachycuje trasy detailne (ani mierka 1 : 50 nie je niekedy postačujúca), konzultácie in situ však spresnia potrebné parametre. Na druhej strane projektant elektro rozvodov musí po realizácii zdokumentovat' (zakreslenie alebo fotodokumentácia) zrealizované trasy pre investora, pre správnu údržbu objektu.

Nakol'ko zasekávanie do drážok nepatrí k reverzibilným zásahom, za nevhodné pri trasovaní môžeme považovat: - nešetrný plošný rozsah drážok;

-najkratšia trasa (sú známe príklady, kedy zničili časti výtvarnej výzdoby pri snahe dosiahnut' najkratšiu trasu a ekonomickú dížku káblov. Obr.1;

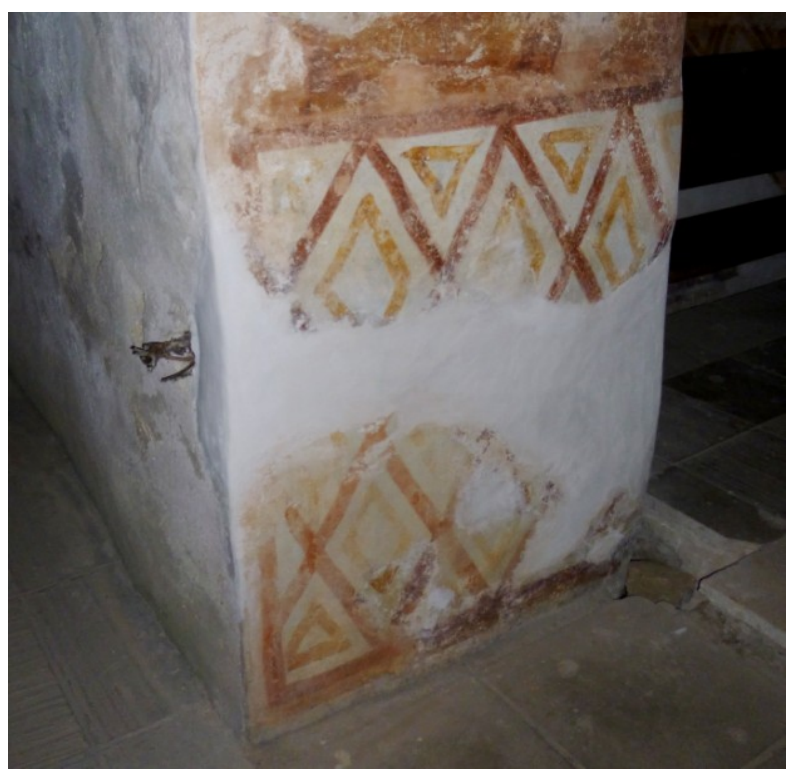

Obr.1a: Ukážka trasy káblov cez miesta s výtvarnou hodnotou (stredoveká mal'ba). 


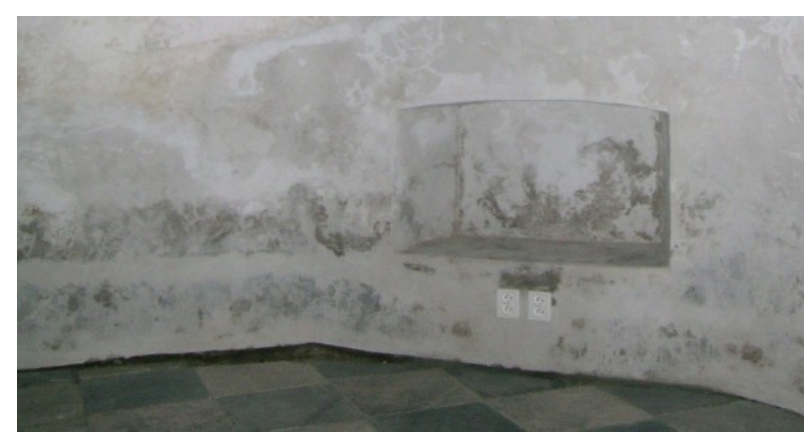

Obr.1b: Ukážka trasovania v murive nad podlahou, pred výmal'bou.

- nevhodné technologické fixovanie káblov v drážke (použit' savé materiály ako cement, sádra nie je vhodné, môže sa objavit' po čase na povrchu ako stopa vlhkosti a zmeny farby), obr.2;

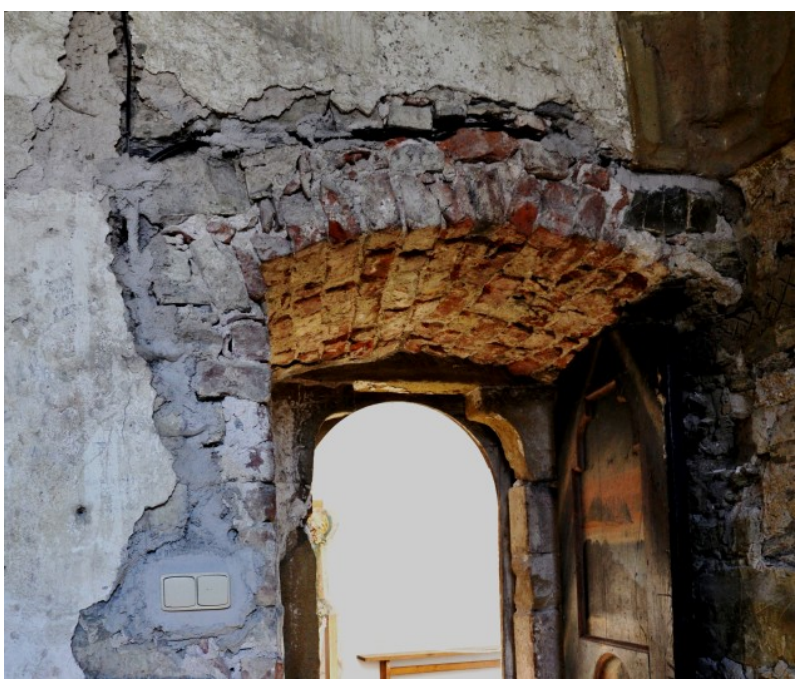

Obr.2: Ukážka deštrukčne realizovaného trasovania a prichytenia káblov váp.- cementovou maltou.

- nedbalá finálna úprava vzniknutej novej plochy (stopa po zásahu nemá byt' viditel'ná v bočnom svetle, čo si niekedy vyžaduje reštaurátorské alebo odborné remeselné postupy)

K trasovaniu rozvodov musíme poukázat' aj na synergetický efekt d'alších pôsobení na technický stav pamiatky [3, Pichová 2010], ktoré rozvody môže značne korigovat'.

Kamenné povrchy dovol'ujú zapustit' káble do špár, rozhodujúca je schopnost' estetickej finálnej úpravy trasy.

V určitých prípadoch intenzívnej výtvarnej výzdoby na architektonických článkoch sa dá uplatnit' riešenie s káblam uchytenými na povrchu. Ak sú farebne prispôsobené pozadiu, nepôsobia rušivo a prakticky zásah do originálu je minimálny a reverzibilný. Obr.3. Trasovanie káblov $\checkmark$ dlaždenej podlahe umožňuje vybrat' potrebné kusy a po položení káblov uložit' do pôvodného stavu. Podlahové trasovanie je výhodné aj $z$ dôvodu združenia rôznych vedení do jedného miesta.

Použitie mobilného kandelábra (stojanového svietidla) predstavuje jedno $z$ bežných riešení, kde nemožno zasahovat' do stien objektu žiadnym zásahom. Vyžaduje si pevný zásuvkový prívod a niekedy vol'ne položené káble na podlahe. Prívod k zásuvke je možné t'ahat' v podlahe, alebo v drážke v stene tesne nad podlahou, kde umelecká výzdoba už nezasahuje. Taktiež v päte stien, zväčša krytým rozvodom na povrchu, kde je dôležité sledovat' vizuálne pôsobenie prekrytia. Sú príklady osvetlenia aj s pevnými

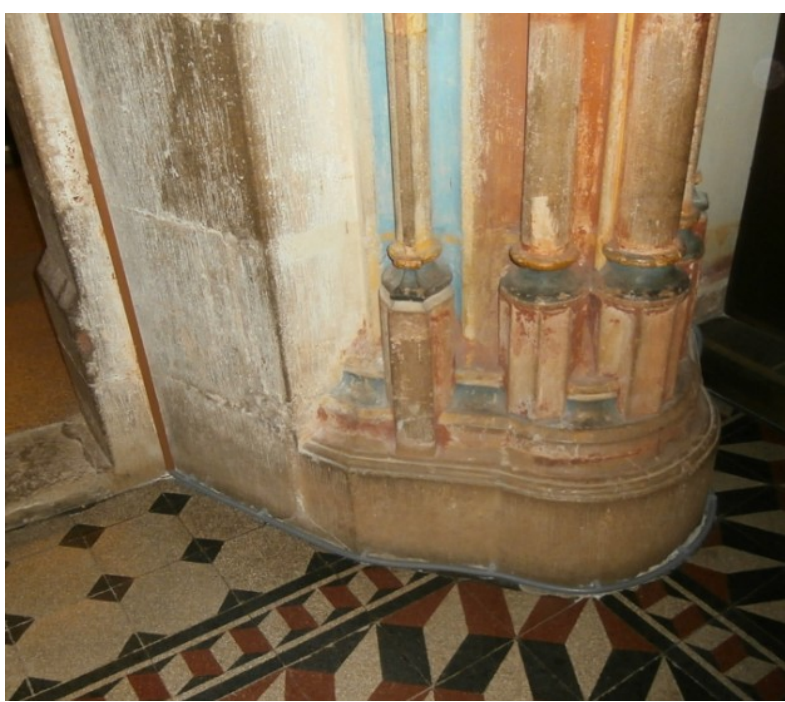

Obr.3: Povrchové trasovanie ako dočasné riešenie je vhodnejšie ako nesprávne zasekanie do omietok a podlahy

stojanmi v podlahe, kedy je ich pozícia definovaná svetelnotechnicky a stavebne (napr. spolu s inou zabudovanou technikou). Zväčša ide o atypické návrhy.

Vol'ba trasy musí byt' výsledkom koncepčného prístupu, ktorý zosúladí vopred všetky zásahy do objektu a overí, aký spôsob osvetl'ovacej sústavy je najvhodnejšie pre daný priestor použit' vzhl'adom k zachovaniu originálov (murivá, výzdoby) a k účinkom.

$\checkmark$ prípadoch striktnej pamiatkovej prezentácie, kedy sa muzeálne prezentujú dejinné obdobia interiérov fungujúcich bez elektriny a pevných svietidiel, sa uplatňujú len zabudované (hlavne zásuvkové) rozvody. Príklad nachádzame u Glosa [4], ako uvádza v súvislosti so slohovou obnovou interiéru kostola do obdobia 18. storočia.

\subsection{Uchytávanie nových telies.}

Kotvenia typových telies do stien prostredníctvom dodávaných úchytiek sú zväčša jednoduché a reverzibilné (podla miesta uchytenia). Ak zostávajú neprekryté, niekedy pôsobia rutinne a technicky (podl'a typu svietidla), čím môžu narušit' snahu o celkové estetické pôsobenie, čo je pri obnove pamiatok rovnako kritérium kvality ako technické náležitosti obnovy, obr.4 a 5.

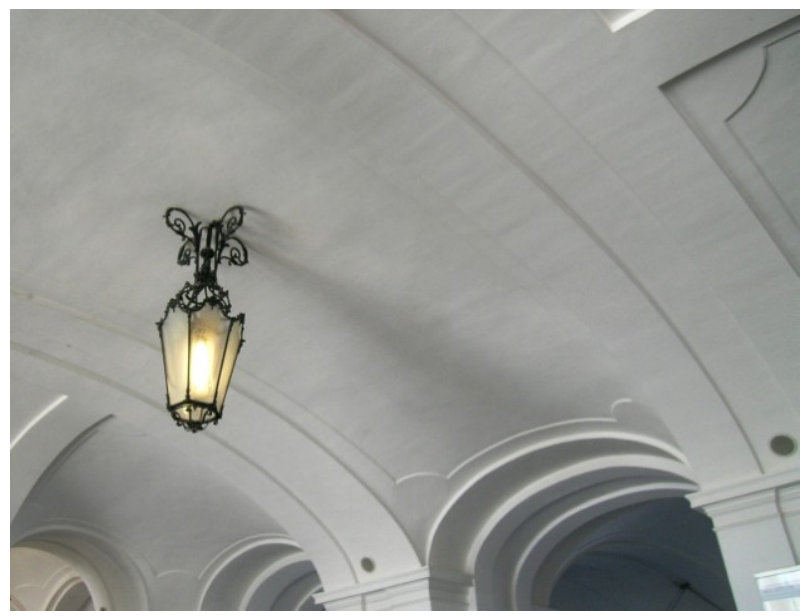

Obr.4: Hladké omietky mladších historických období nesmú niest' stopy po trasovaní káblov. (vol'ba prístupu zhora) 


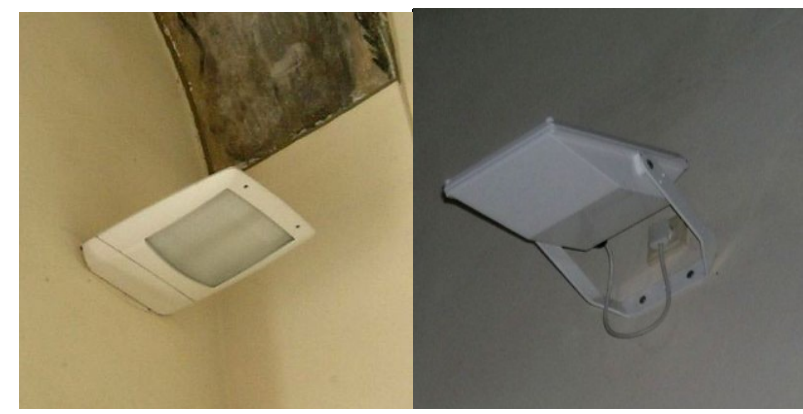

Obr. 5a: Vhodné a menej vhodné uchytenie svietidla, ktoré esteicky narúša celkový vzhl'ad historického interiéru.

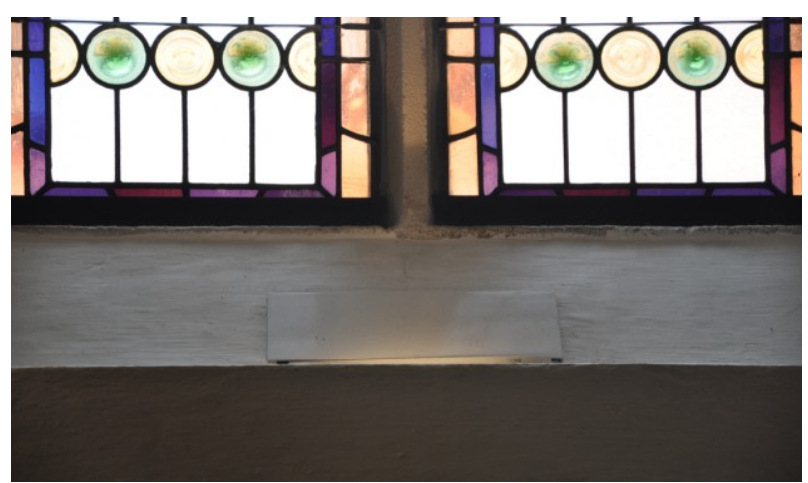

Obr. 5b: Akceptovatel'né umiestnenie svietidla v nike parapetu okna $v$ danej situácii. Svietidlo má difúzor splývajúci s povrchom.

Pamiatkovo sledovanejším problémom sú nové otvory v klenbách (cca $\varnothing 50-60 \mathrm{~mm}$, obr.5) a kotviace systémy novo navrhovaných zavesených lustrov (zavesenie, fixovanie smerovania, spúšt'anie, ovládanie pohybu). Tie môžu vyvolat' zásahy do konštrukcií krovu a drobné zásahy v podkroví. Samotný otvor nesmie narušit' výzdobu klenby (pri vítaní, ani umiestnením), pokial' je vôbec takýto návrh pamiatkovo akceptovaný.

$\checkmark$ podkroviach možno umiestňovat' aj elektro rozvodné skrine $s$ vel'kými rozmermi $v$ prípade, že nové búracie zásahy by nebolo možné uskutočnit' v prízemí alebo na poschodiach. Toto riešenie je frekventovane používané, aj vzhl'adom k rozsahu dnešnej väčšej elektrifikácii objektov a určitej energetickej rezervy. Vyžaduje si nájst' kompromisné miesta prierazov z krovu do dolného priestoru, pričom sa "ušeti” väčší zásah. Obr.6.

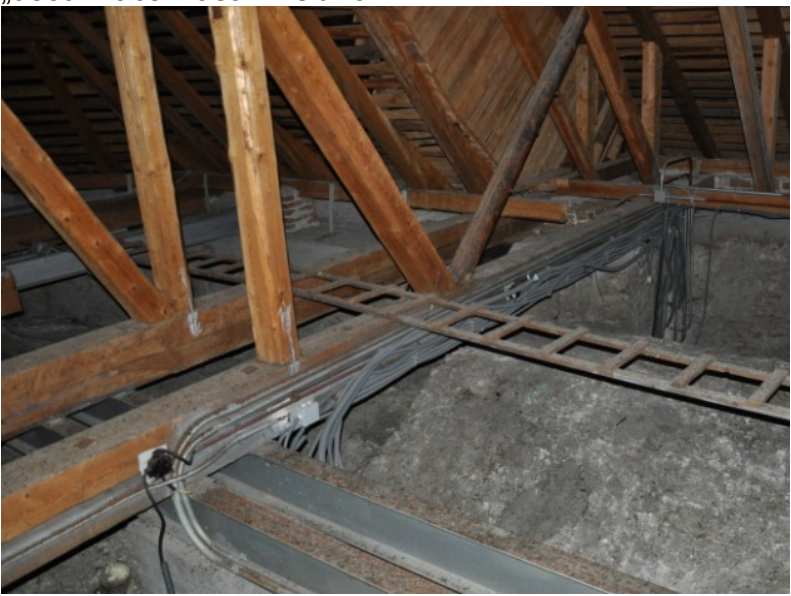

Obr.6. Uchytenie priamo na prvky krovu treba okrem iného (požiarna ochrana, statika....) konzultovat' aj z hl'adiska pamiatkového ( pre prípady s významnou hodnotou veku a konštrukcie).

\subsection{Existujúce / pôvodné vedenia a staré osvetl'ovacie telesá.}

Pri rekonštrukciách elektro sietí je dobré preverit' staršie trasovanie pre novú kabeláž a skrine a využit' možnost' starších stavebných zásahov: drážky, niky, prierazy,... alebo ich úseky, aby nedochádzalo k zbytočným novým búraniam. Z hladiska prezentácie pamiatok si odstraňovanie nepoužívaných zabudovaných prvkov osvetlení (či už z hladiska účinkov alebo prekonanej osvetl'ovacej techniky) vyžaduje sanáciu povrchov do pôvodného stavu.

Pri strate umelecko-historickej hodnoty zo staršej realizácie, ktorá narušila stavebnú alebo interiérovú substanciu, treba následne pri novej realizácii použit' korekčné prístupy $s$ dohl'adom reštaurátora. Čo zvyšuje rozpočet a náklady treba predpokladat' vopred. Na druhej strane, vyskytujú sa prípady, kedy odstránenie starších prvkov pamiatke prospeje (svietidlá, rôzne bandáže...), obr.7.

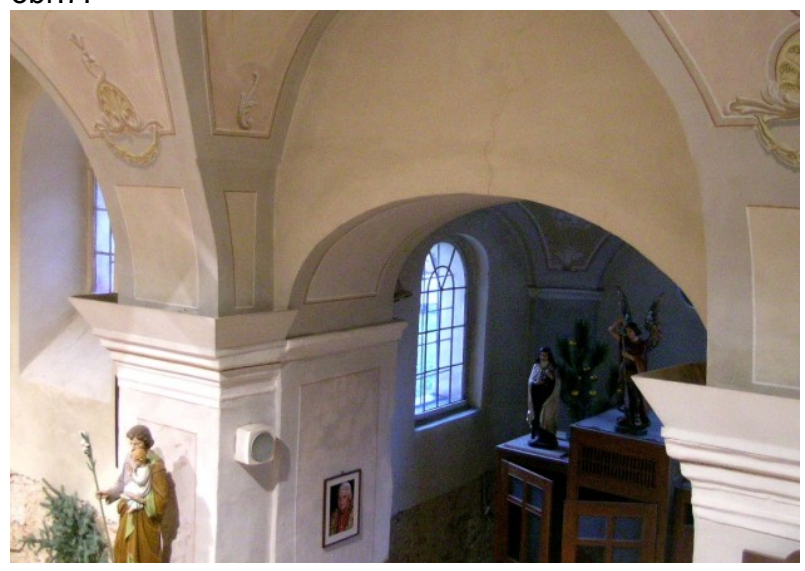

Obr.7: Nevhodné bandáže zastaralých svietidiel na rímsach narúšajú pôvodné proporcie hlavíc pilierov, potrebné odstránit'.

Ďalším momentom je situácia, kedy sa predmetom pamiatkovej ochrany môžu stat' staršie osvetl'ovacie telesá (atypické aj typové výrobky) a výnimočne aj elektro rozvody - ako doklady historického vývoja objektu a techniky. Obr.8. Tento trend slohovej obnovy vidíme najmä $\vee$ pamiatkovej ochrane modernej architektúry. Obr.9.

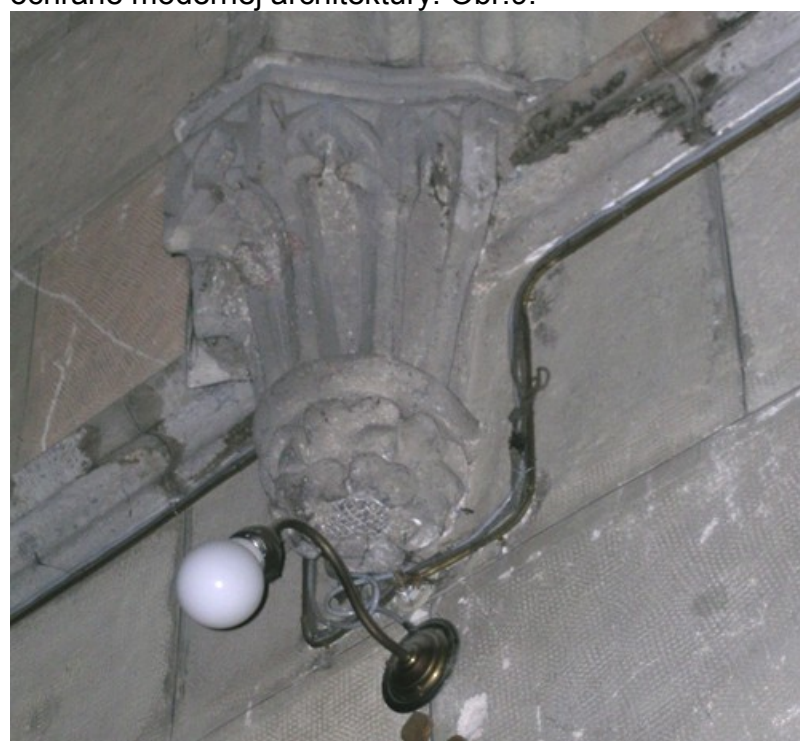

Obr.8: Príklad starších mosadzných rozvodov so svietidlom. Zachovanie takejto osvetl'ovacej sústavy „in situ” a v akom rozsahu, treba konzultovat's pamiatkovým úradom. 


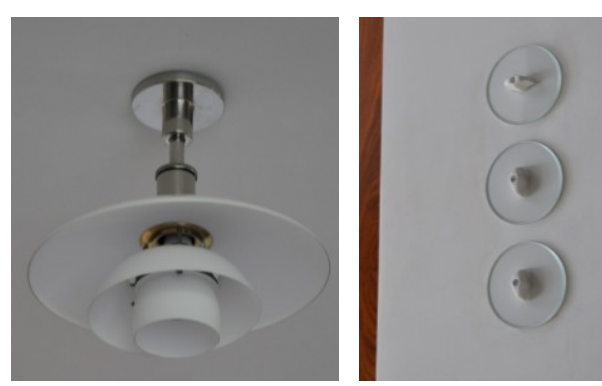

Obr.9: Príklad rekonštrukcie rozvodov s výbornou úpravou povrchov stien; prvky sú zachované a repasované.

$\checkmark$ niektorých prípadoch sa stretneme so zapísanými svietidlami ako hnutel'nými pamiatkami, s ktorými treba náležite zaobchádzat'. Ich svetelná modernizácia je opät' na konzultácii s pamiatkovým úradom. Rovnako upravené ich pozície - ako výšky zavesenia, premiestnenie a podobne. Obr.10
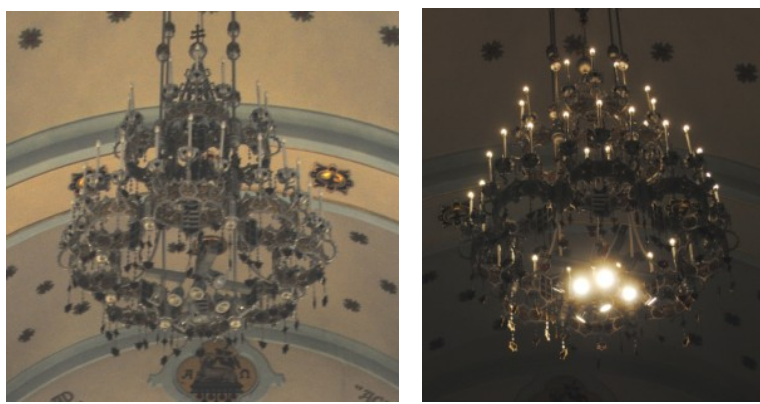

Obr.10:

Modernizácia historického lustra - doplnenie v dolnej časti.

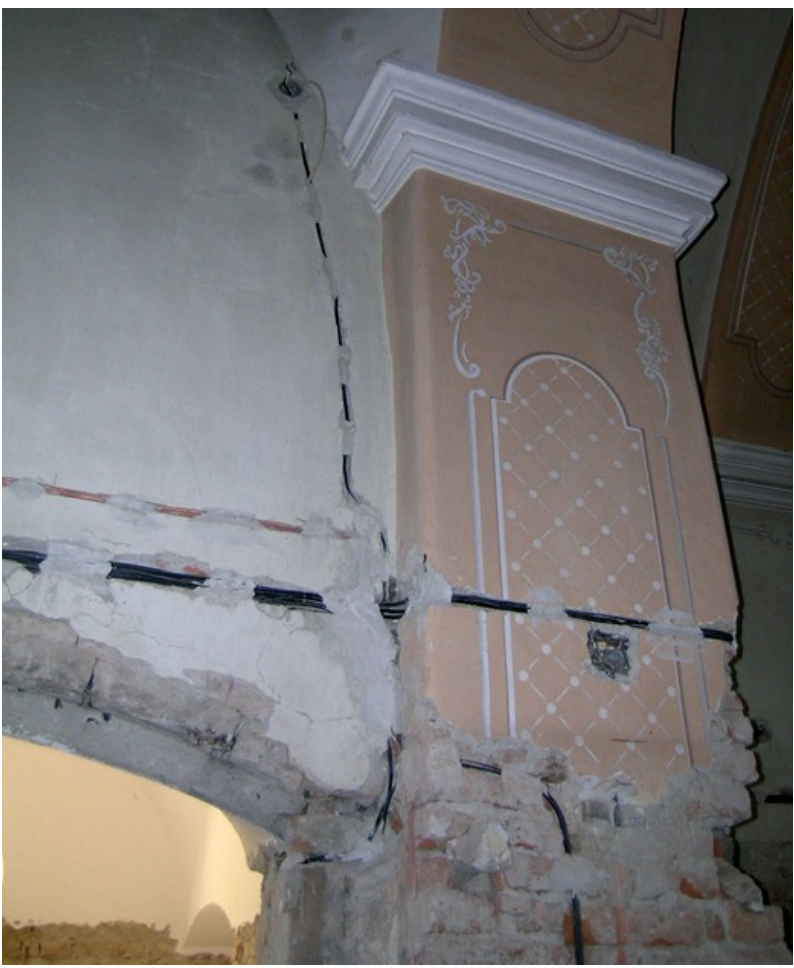

Obr.11: Logika trás je definovaná kultúrno-historickou hodnotou podkladu aj schopnost'ou vykonat' technologicky správne a esteticky nerušivo nové prekrytia (retuše) tak, aby nový celkový povrch plochy bol bez stopy zásahu.

\subsection{Reverzibilita zásahu ako kritérium.}

Nároky novej osvetl'ovacej sústavy vnášajú oprávnené požiadavky na drobné zásahy do originálu stavebných častí pamiatky: prierazy konštrukciami, drážky, rozšírenie ník, dopíňanie konštrukcií...a d'alšie. Podrobnejšie problematiku elektrorozvodov uvádza Števko [5, 2008], poukazuje na technickú a legislatívnu nárokovatel'nost' aj pri pamiatkach,ako aj realizačnú zložitost'.

Pri každom konkrétnom prípade treba vziat' do úvahy dôsledky nových elektrických zariadení (hodnota murív a omietkových vrstiev pod trasou) a rozsahu deštruktívneho zásahu (vel'kost' prierazov..) versus jeho prínosy. Tu je práve reverzibilita zásahu do hmotnej povahy objektu kritériom pri rozhodovaní a prípadnej úprave celého návrhu osvetlenia. Obr.11.

\section{Závery}

3.1 Návrh a realizáciu osvetlenia je nutné vykonávat' v súčinnosti s pamiatkovou ochranou. Elektro-dokumentácia sa musí opierat' o koncept (architektonický koncept osvetlenia), ktorý berie do úvahy nielen návrhy svetelnotechnické a elektrotechnické, ale aj otázky pamiatkovej ochrany a nových zásahov v objekte. Interdisciplinárny prístup šetrí čas aj náklady.

3.2 Miera rozsahu zásahov do hmotnej substancie si vyžaduje:

- prijat' ako nevyhnutnú zásadu reverzibility; volit' sofistikovaný prístup porovnávaním viacerých postupov tak, aby neutrpela podstatná hodnota pamiatky;

- už pri projektovej dokumentácii sledovat' zo strany pamiatkovej ochrany trasovania káblov a umiestnenie elektrických zariadení; minimalizovanie trás spravidla nie je primárnym determinantom vol'by z hl'adiska obnovy pamiatky; zároveň treba byt' otvorení voči zmenám vzniknutým pri realizácii; požadovat' koordináciu s d'alšími siet'ami;

zhotovit' fotodokumentáciu realizovaných novo trasovaných rozvodov s možnost'ou identifikácie polohy; nové technológie (napr. ploché prierezy káblov, ich farebnost', krycie lišty...) môžu prispiet' k prijatel'ným reverzibilným riešeniam;

- dodržat' technologicky správne postupy na historických murivách (nekvalita sa objaví po dlhšom čase);

- zriadit' lapidárium starších odložených svietidiel na úrovni pamiatkových úradov.

\section{Referencie}

[1] Gregor,P a kol.: Zásady a metódy ochrany a obnovy historických objektov a súborov. In: Obnova pamiatok. Perfekt. Bratislava 2008, s.94.

[2] Erdélyi,R.:Terminológia. In: stránka Ohrozené kostoly, http://www.ohrozenekostoly.sk/db/terminologia,

[3] Pichová,M.:Sakrálne objekty - sanácia, vykurovanie, vetranie, plesne. In: Bardkontakt 2010. Zborník z konferencie, MÚ Bardejov, 2010. s.38.

[4] Glos,P.Obnova interiéru kostola v Červenom kláštore. In: Bardkontakt 2010. Zborník z konferencie, MÚ Bardejov, 2010. s.134

[5] Števko,M.: Kto a čo umožňuje pamiatkam prežit'? Problematika riešenia elektrických rozvodov. In: Monumentorum tutela č.19., PU SR 2008, str.87- 92

Zdroje obrázkov: Archív autorky. Obr.10: K. Kalašová, 07/2015.

Author: Ing.arch. Beata Polomová, PhD., Slovenská technická univerzita - Fakulta architektúry; Nám. Slobody 19, 81245 Bratislava, Slovensko. e-mail: beata.polomova@stuba.sk. 